\title{
Study of Urban Drainage Network Performance in Maximum Discharge Storage in the City of Bandung
}

\section{Rakhmat Yusuf}

Civil Engineering Study Program, Indonesia University of Education, Bandung, Indonesia

\section{Abstract}

The analysis of Urban Drainage Network Performance in Maximum Discharge Storage in the City becomes an urgent matter, the approach that will be conducted in this research is explanatory, which is explaining natural phenomena that happened and synthesizing the relation of parameter stream, existing drainage network, and potential puddle.

The result of analysis shows several inundation area in the rainy season in subCatchment Citepus, the cause is identified as there has not been a drainage channel that connects it to the main canal that caused the drainage network hard to be

Corresponding Author:

Rakhmat Yusuf

rakhmatyusuf@upi.edu

Received: 11 January 2019

Accepted: 14 February 2019

Published: 25 March 2019

Publishing services provided by Knowledge E

(c) Rakhmat Yusuf. This article is distributed under the terms of the Creative Commons

Attribution License, which permits unrestricted use and redistribution provided that the original author and source are credited.

Selection and Peer-review under the responsibility of the $3 \mathrm{rd}$ ICTVET 2018 Conference Committee. evaluated, the water rope are clogged beside the road, dimensional channel cannot handle runoff discharge, various clog on several crossway, the narrowing and swallowing of channel because of sedimentation, and several different utility with the transversal and parallel in position causing it to become a place where garbage stacks up. Several channel section's capacity are unable to contain discharge, but several channel are still able to contain but in factuality of the field there are still rash that caused inundation in several main section roadway in Bandung.

Keywords: discharge, inundation, flood, drainage.

\section{Introduction}

Flood is an effect response caused by human activity in natural space that shows imbalance in exploiting nature, the velocities of life that becomes uncontrollable, and so nature responded. Rain is a familiar natural phenomenon for human life, however when rain falls on its catchment area that has been destructed, it will cause an excessive run off and according to hydrology cycle, the intended infiltration component that is big should happen but instead the land covering impervious increased exponentially, which cause run off to increase in the existing drainage network, the existing drainage facility has not been evaluated when compared to the fast land covering caused by human activity, so it caused over flow in the city's drainage channel.

\section{S OPEN ACCESS}




\section{Methods and Equipment}

The research is using the analytic explanatory method, which is the research that will explain the natural phenomenon in the field in great detail and synthesizing the relations among component of streams and the existing drainage facility to the phenomenon of inundation that often happened in the urban area. The location of Bandung City is in the basin that can cause a problem in itself for the drainage network outlet, technical solution is needed so rain could be drained in the run of stream.

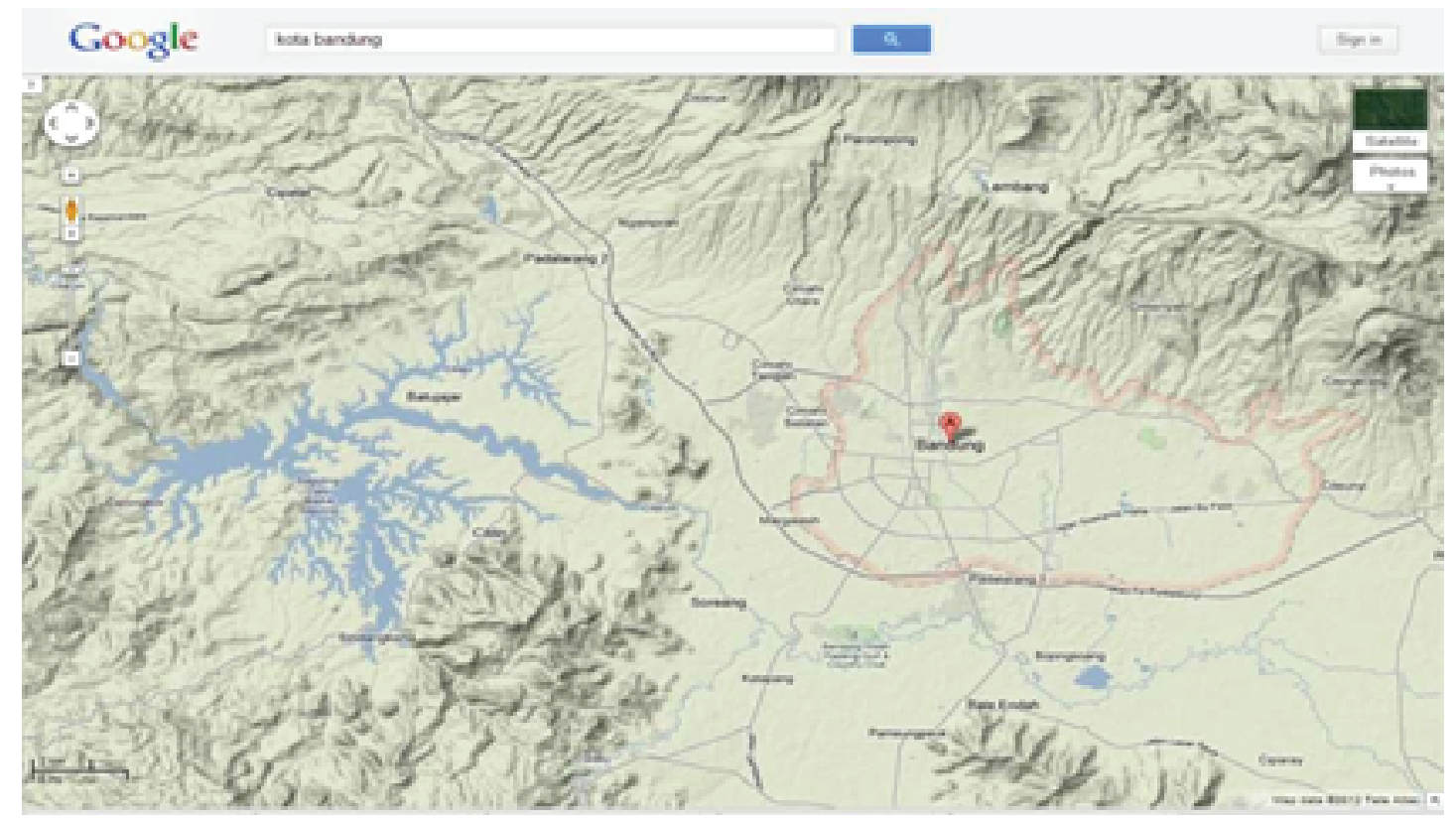

Figure 1: Bandung Basin (www.google.com).

\section{Result}

A landscape about the land usage in the bank of Sub DAS Citepus is as follows:

1. The Slum Settlement are visible across the route od Sub-Catchment Citepus if crowded by settlement. Many upstream of Sub-Catchment Citepus are more arranged compared to middle and downstream area which contains many slum settlement that build house in river border

2. The construction site MCK in the near river that utilize river body and border. 


\subsection{River network}

River Network that is located in Sub-Catchment Citepus consists of Main River which is Citepus River and several tributary that connects directly to Citepus River. Those tributaries are Cilimus river, Cikakak river, Cipedes river, Sukamulya River, Sukahaji river, Cibogo river and Ciroyom river. Catchment area of Citepus is $\pm 2330,05$ ha covers the area from Ledeng in the north until the border of Kabupaten Bandung in the South. The River Network System in Sub-Catchment Citepus can be seen in Figure 2.

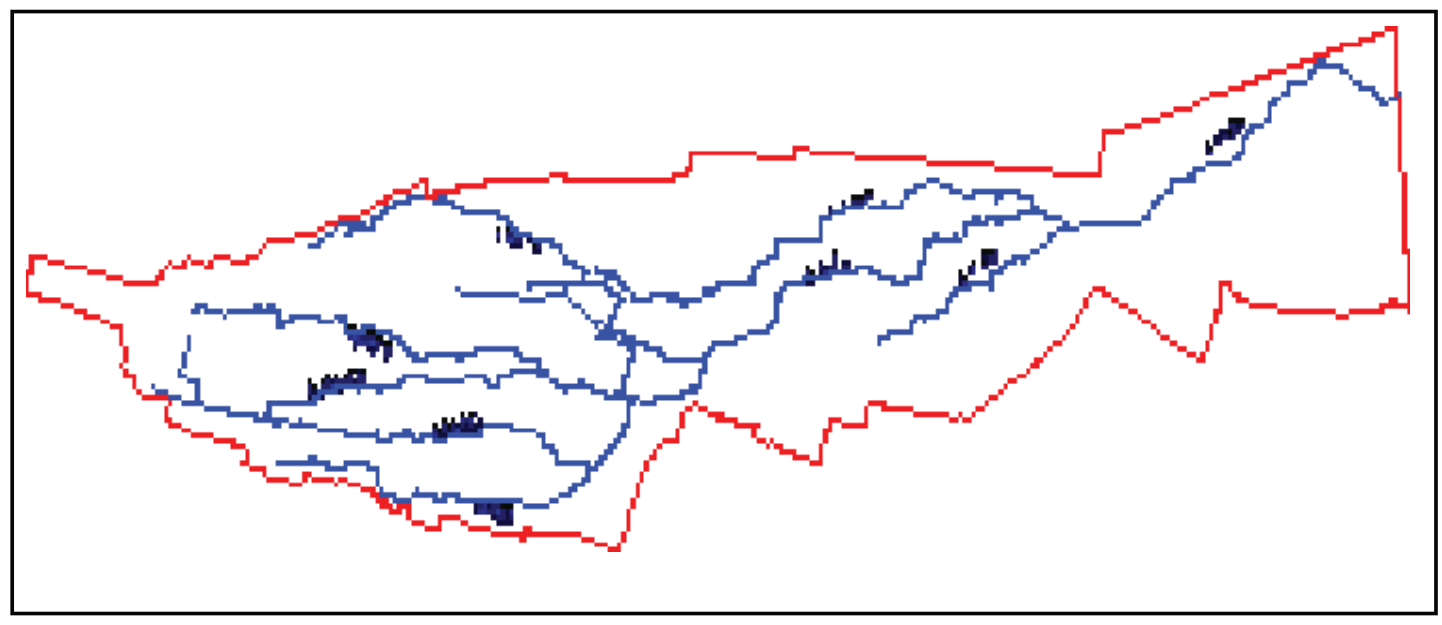

Figure 2: River Network Citepus Sub-Catchment (Source: Inventarisasi Saluran Drainase Sungai SubCatchment Citepus, Kota Bandung, 2010).

\subsection{Condition of drainage infrastructure}

Drainage System in Bandung City generally utilizing the already available river. In SubCatchment Citepus, Citepus River and tributaries which are Cikakak, Ciroyom, Cipedes, Cilimus, Sukahaji, Sukamulya, and Cibogo functions as the main drainage channel, while drainage channel area are in the form of of channel beside the road. The condition of this channel generally fulfilled its main capacity as the drainage area. Also, the main problem that becomes the important issue is the inundation that happen because the lack of channel that meet the requirements to drop the drainage weight. This condition can be seen in several road like Pasteur, Pagarsih, Mohammad Toha, etc.

\subsubsection{Inundation Identification}

The general cause of inundation flood is Drainage System didn't function optimally, the cause is as follows: 
1. No Drainage channel that connects to main channel;

2. Water Channel are clogged beside the road;

3. Channel Dimension is inadequate compared to weight of discharge drop from the service area;

4. Blockage in the crossway in the form of sediment and garbage;

5. Sharp Turn;

6. Narrowing Channel that cause bottle neck;

7. The Other utilities like pipe and cable are placed in parallel and are in the way.

From the inventory that has been done, there are at least 21 point of flood inundation in Sub-Catchment Citepus. The location is spread equally in every part from the Downstream to the Upstream of Sub- Catchment Citepus

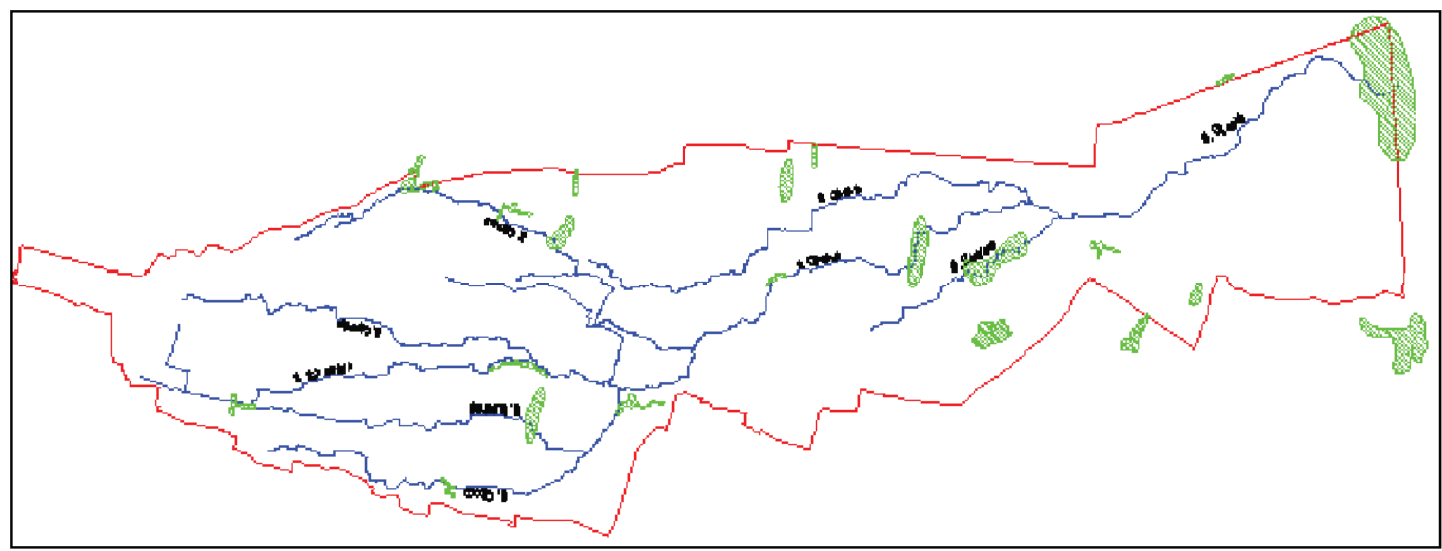

Figure 3: Inundation location of Citepus Sub-Catchment (Source: Bina Marga dan Pengairan (2010)).

\subsection{River condition and channel}

Citepus River is the main river of Sub-Catchment Citepus before flow to Citarum River. The length of Citepus River estimately is $10,06 \mathrm{~km}$ measured from the Purbaleunyi Highway until the meetings of Cipedes River and Sukamulya River.

The problems occurred in Citepus River are the destruction of wall made from the river stone. Other problems are the many buildings built upon the river border and road inspections have not been done. This condition cause the maintenance cannot be done properly which cause sediment and garbage to stack in the river are unable to be cleared. Because the decrease of cross section, the big discharge of river cannot contain it which cause the run off in several spot. 
Also the narrowing and sharp turn causing bottle neck that overflows to certain area. This situation happens in Pagarsih Road, where Citepus River narrows and sharp turn until the overflow reach the Citepus Bridge.

\subsection{Rain data analysis}

Maximum rain per minute in Rainfall Station Cemara from the year 1986 until 2014. With the duration of $5,10,15,30,45,60,120,180,360,720$ minutes. To the data, test was conducted on consistency rain data test, calculation analysis frequency and probability also calculating the intensity of rainfall.

\subsubsection{Rain consistency data test}

Rain Consistency Data test is conducted with the RAPS method to find out if the data acquired can be used or not. According to the consistency test with RAPS method, data is stated as Consistent $\mathrm{R}<$ Rcritic

\subsubsection{Analysis frequency and probability}

From the result of test, acquired the result that the method of Log Pearson Type III Distribution most fit to be used in the calculation analysis frequency because in the test of Smirnov-Kolmogorov and Leaster was acquired that Log Pearson Distribution has the smallest Dmax value. With the frequency analysis of rainfall maximum for the 5 minutes duration until 720 minutes can be decided with the Log Pearson Type III

\subsubsection{Rain intensity}

Rain intensity is calculated with the Talbot equation after several test with other method was conducted.

\subsubsection{Calculation and analysis of the capacity of existing drainage chan- nel in Jalan Pagarsih}

According to the drainage principle in which it was functioned as disposal channel for the rain water that flows on the surface can be disposed quickly so it won't cause inundation that can hinder daily activity and cause problems. 
TABLE 1: Maximum Rainfall Data Station.

\begin{tabular}{|c|c|c|c|c|c|c|c|c|c|c|}
\hline \multirow[t]{2}{*}{ Years } & \multicolumn{10}{|c|}{ Duration (Minute) } \\
\hline & 5 & 10 & 15 & 30 & 45 & 60 & 120 & 180 & 360 & 720 \\
\hline 1986 & 10.0 & 20.0 & 28.5 & 43.0 & 48.8 & 52.0 & 58.0 & 59.0 & 63.0 & 63.1 \\
\hline 1987 & 13.1 & 19.8 & 22.2 & 36.4 & 48.5 & 50.6 & 54.6 & 57.8 & 72.1 & 73.1 \\
\hline 1989 & 9.8 & 19.6 & 28.9 & 40.4 & 46.2 & 47.4 & 60.8 & 66.3 & 66.5 & 68.2 \\
\hline 1990 & 12.8 & 18.9 & 20.0 & 30.0 & 40.0 & 50.0 & 52.6 & 52.6 & 57.5 & 80.2 \\
\hline 1991 & 20.0 & 26.0 & 36.0 & 46.0 & 53.0 & 55.0 & 56.0 & 56.9 & 64.2 & 65.7 \\
\hline 1992 & 20.0 & 23.0 & 27.0 & 38.0 & 50.2 & 51.9 & 59.4 & 59.4 & 75.5 & 78.4 \\
\hline 1993 & 8.9 & 16.8 & 24.7 & 31.6 & 42.9 & 41.9 & 46.2 & 46.8 & 53.5 & 53.5 \\
\hline 1994 & 15.0 & 21.0 & 25.3 & 34.5 & 35.7 & 38.1 & 51.2 & 53.1 & 53.3 & 60.3 \\
\hline 1995 & 9.2 & 19.3 & 23.1 & 31.5 & 42.0 & 46.0 & 46.9 & 48.7 & 48.7 & 66.9 \\
\hline 1996 & 18.6 & 23.6 & 28.3 & 38.0 & 41.3 & 45.8 & 59.4 & 73.6 & 79.6 & 81.3 \\
\hline 1997 & 15.0 & 20.0 & 30.0 & 45.9 & 48.1 & 50.0 & 51.5 & 53.4 & 60.5 & 67.9 \\
\hline 1998 & 14.5 & 20.0 & 30.0 & 36.2 & 58.0 & 62.2 & 62.2 & 75.0 & 82.5 & 83.8 \\
\hline 1999 & 9.5 & 11.6 & 15.0 & 26.5 & 41.3 & 46.8 & 57.5 & 64.3 & 70.1 & 70.8 \\
\hline 2000 & 12.5 & 15.0 & 20.5 & 32.9 & 40.3 & 46.5 & 57.3 & 62.4 & 95.4 & 95.8 \\
\hline 2001 & 14.7 & 21.7 & 25.2 & 38.0 & 47.0 & 48.5 & 54.0 & 54.0 & 54.0 & 54.0 \\
\hline 2002 & 36.5 & 19.0 & 22.0 & 36.5 & 42.6 & 46.5 & 53.6 & 62.2 & 72.1 & 73.7 \\
\hline 2003 & 7.4 & 16.5 & 23.0 & 36.4 & 43.3 & 50.0 & 54.0 & 66.5 & 66.5 & 66.5 \\
\hline 2004 & 10.0 & 20.0 & 30.0 & 44.2 & 51.2 & 51.2 & 52.2 & 55.8 & 70.0 & 72.6 \\
\hline 2005 & 13.5 & 25.0 & 25.0 & 73.0 & 44.0 & 71.0 & 73.0 & 68.8 & 80.3 & 80.9 \\
\hline 2006 & 40.0 & 20.0 & 25.0 & 40.0 & 40.0 & 45.2 & 60.9 & 75.8 & 89.3 & 94.3 \\
\hline 2007 & 20.0 & 30.0 & 42.0 & 60.0 & 85.0 & 65.0 & 75.0 & 66.7 & 69.7 & 69.7 \\
\hline 2008 & 25.4 & 26.0 & 30.0 & 51.8 & 52.0 & 52.0 & 59.8 & 67.8 & 67.8 & 67.8 \\
\hline 2009 & 40.1 & 28.0 & 28.0 & 40.1 & 52.8 & 53.6 & 53.7 & 71.5 & 81.9 & 82.0 \\
\hline 2010 & 25.0 & 35.0 & 40.0 & 58.0 & 62.0 & 70.3 & 84.5 & 87.0 & 115.6 & 115.6 \\
\hline 2011 & 13.0 & 27.5 & 32.0 & 41.0 & 54.0 & 65.0 & 75.0 & 75.0 & 75.0 & 75.0 \\
\hline 2012 & 30.0 & 30.0 & 35.0 & 60.0 & 68.1 & 68.1 & 68.1 & 68.1 & 78.9 & 83.4 \\
\hline 2013 & 22.0 & 22.0 & 30.0 & 52.0 & 59.2 & 63.0 & 67.8 & 69.2 & 70.4 & 70.4 \\
\hline 2014 & 16.0 & 31.0 & 41.0 & 58.0 & 73.0 & 87.0 & 108.7 & 112.5 & 113.8 & 113.8 \\
\hline \multicolumn{11}{|c|}{ Source: - Stasiun Geofisika Kelas 1 Bandung (BMKG Cemara) } \\
\hline & & & & & & & & & & \\
\hline
\end{tabular}

As it has been analyzed before that the drainage channel functions as the route for rain water disposal to prevent the inundation in certain area. Jalan Pagarsih is a road with very crowded traffic. Also this area is very populated. The use of land in this area is for the settlement of people.

Drainage in the Pagarsih road is made from the couple of river water, with the width of 1 meter and the depth of 1 meter. The source of water disposal is dropped to the 


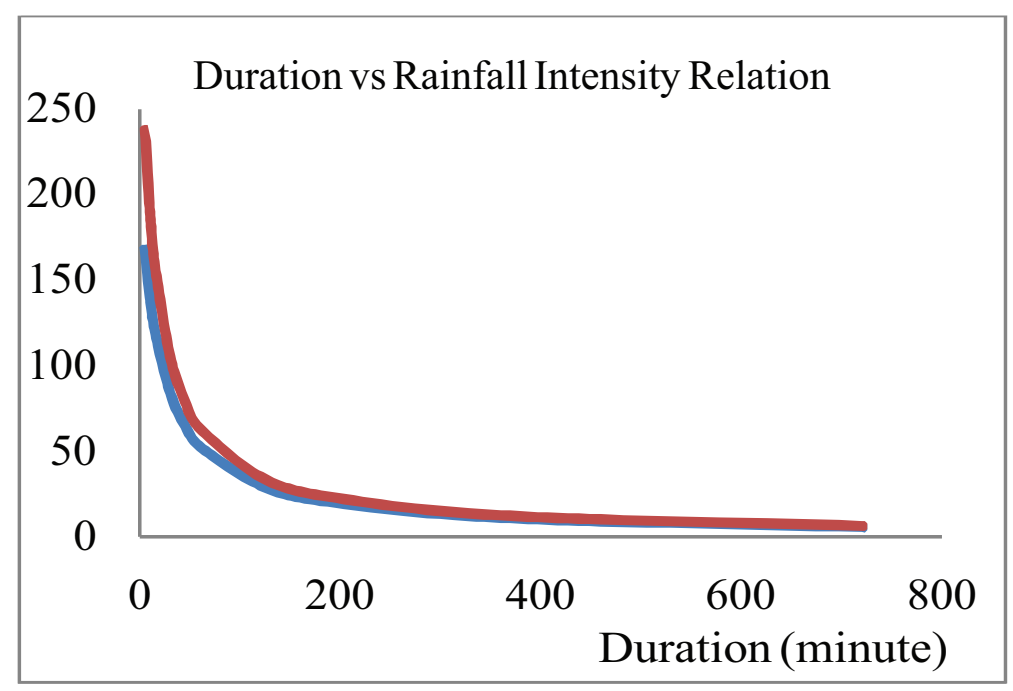

Figure 4: Relation between duration vs rainfall intensity return period 2 and 5 years.

Pagarsih drainage coming from the domestic water disposal from household, also from the infiltration of rain.

Drainage in the Pagarsih road disembogues to the Citepus River. According to direct observation in the field, the condition of the drainage in Pagarsih road is very poor. The Channel is filled with sediment and garbage that cause the water flow to be slow and the ability to contain water is not optimal that cause overflow when it rains.

The result of existing drainage in capacity in Pagarsih, discharge that happened is bigger than the channel capacity, redesign is need to prevent overflow. According to the result of analysis, the existing channel of 7-8 kr inside the Jalan Pagarsih, channel capacity cannot fill the planned discharge. This caused water to overflow and inundate Jalan Pagarsih. The result of redesign the channel with bas width of 1.00 meter, height of 1,20 meter with the freeboard of 0,30 meter is able to contain the discharge of 0739 $\mathrm{m}^{3} /$ det.

\section{Discussion}

The Inundation is one of the primary problems that happened in Bandung City. It happened because the lack of drainage channel that can contain the discharge of rain water in certain area. The parameter of inundation covers the height of inundation, large of inundation and the duration the inundation happened. Jalan Pagarsih is one of the area that never missed from the problem of inundation whenever the rain falls. From the result of observation, it was found that the height of inundation in Jalan Pagarsih 
is about $30-50 \mathrm{~cm}$ and duration is one hour, meanwhile for the width of inundation is about 0,8 Ha.

The main cause of the inundation in Jalan Pagarsih are, existing drainage channel capacity that could not handle the rain water discharge, overflow of Citepus River, and also the many sedimentation and garbage that decrease the capacity of channel and river.

The Effect from the inundation is, the traffic being hampered in Jalan Pagarsih, household are being inundated, and also destroying nearby facilities.

Citepus River which is near Jalan pagarsih is the main river of Sub-Catchment Citepus, the lenght of Citepus River estimated of $10,06 \mathrm{~km}$ that can be measured from the highway of Purbaleunyi until the meetings of Cipedes River and Sukamulya River.

The problems occurred in Citepus River are the destruction of wall made from the river stone. Other problems are the many buildings built upon the river border and road inspections have not been done.

This condition cause the maintenance cannot be done properly which cause sediment and garbage to stack in the river are unable to be cleared. Because the decrease of cross section, the big discharge of river cannot contain it which causes the run off in several spot.

Maintenance and care for the river is also the Authority of PSDA. Like has been mentioned, because the lack of read inspection there is on maintenance that can be maximally performed, this cause sediment and garbage in the river cannot be cleared out.

Citepus River that overflows is also the cause of inundation in Jalan Pagarsih. Inundation that is cause by the river is estimated to be $30-50 \mathrm{~cm}$ in height and inundate area near jalan pagarsih. From the observation, it was acquired that there is so many sedimentation and garbage.

Like has been mentioned that garbage and sedimentation in the Citepus River has caused the river capacity to be decreased, so it was unable to contain the discharge in maximum, this cause drainage function in Jalan Pagarsih to be disturbed that made Citepus River body as receiver.

Not only the garbage and sedimentation that is carried by Citepus river when it overflows to the drainage rout in Jalan Pagarsih, the result of it that the existing drainage in Jalan pagarsih is decreased and unable to contain planned discharge. 
According to the limitation of problem, in this research, the writer is also limiting the research until the analysis of existing drainage capacity channel in Jalan Pagarsih. So that for the discussion of overflows of Citepus River won't be discussed in detail.

In this research, the writer analyzed the capacity of existing drainage channel in Jalan Pagarsih with the purpose of finding out whether the drainage channel in Jalan Pagarsih is able to fulfill the planned discharge or not.

The Drainage that has been researched is an existing drainage of Jalan Pagarsih in Left and Right Segment, for the lenght of $\pm 1,3 \mathrm{~km}$. Existing drainage in left segment receives water from the nearby settlement, while the right segment only receive water from the Halan Pagasih. According to the result of field observation the condition of Drainage in Jalan Pagarsih is very poor, the drainage channel is filled with sedimentation and garbage, it is disturbing the workings of said drainage channel.

From the result of calculation it is acquired that existing drainage channel of 7-8 Kr has the height of one meter, and the widht of one meter. As for the capacity of channel of 7-8 $\mathrm{Kr}$ has acquired $0,655 \mathrm{~m}^{3} / \mathrm{second}$.

The channel is decided to be able to contain planned discharge if Qsaluran is bigger than Qrencana, and if Qsaluran is smaller than Qrencana, It can be said that the channel cannot contain planned discharge. For the drainage channel 7-8 Kr in the Jalan Pagarsih it can be concluded that Qsaluran is smaller than Qrencana, As the result of it the water will overflow in those channel and inundate nearby areas. From those calculation, the result is acquired that the height of inundation in the area of those channel is $10 \mathrm{~cm}$, and for the inundated area is about 0,35 HA. As for the duration of Inundation is 60 minutes.

The Important parameter that becomes the basis for the analyisis discharge of runoff in evaluating the capacity of border channel is coefficient runoff $\mathrm{C}$, for the urban condition with the settlement and industrial area Magnitude $C$ is taken as 0.85 (S. Hindarko, 2000:52).

As for the rough parameter basis of channel Manning approach is used for the open unmaintained channel $n=0,050-0,10$ (Ned HC. Hwang, 1981:148).

Analysis Result Capacity border contains several segment channel in which condition of capacity is unable to contain the discharge of short retrial period, and the reality according to the information from the nearby citizen who states that the inundation is very often and could reach 30 to $40 \mathrm{~cm}$, according to the calculation of channel capacity is not adequate, added to that the decrease of wet border channel because of sedimentation and mud, the amount of garbage that stuck also cause the channel capacity cannot hold discharge, so it overflows to either side of the road, that cause 
Flood. The result of analysis is several segments of the channel is not adequate in its capacity like in Jalan Sukamulya Cipedes, Jalan Dr. Djundjunan, Jalan Kopo, Terminal Leuwipanjang, Jalan Cipaganti, Jalan Setiabudi. However there are several channel that has the capacity to hold discharge runoff caused by rain, but the fact in the field is overflow happens until it cause inundation for the duration of rainfall, this situation can be explained that even the capacity is adequate but the garbage that is carried by the stream cause overflow it can still cause an inundation, because garbage carried by the stream can by stuck in the utility like cable or pipe, these utility is also function for the needs of the people but the placement in the same channel will cause the decrease in the capacity that will cause overflow. In several channel shows sediment in its base, as the result of soil material runoff in the surface of Sub- Catchment Citepus Stream.

The more the surface of earth covered in concrete that can't absorb water, the more the amount of runoff in the surface will increase, the closing of the land is caused by human activity in building, whether it is house, road, concreted yard, small roads that has been hardened by concrete so it is impossible for water to infiltrate perfectly.

Several cross section channel went through a narrowing, like in Jalan Cibogo near the elementary school, the channel narrows from 2 meters until 1 meters, the area near Cibogo is often inundate that can last for 2 hours, and disturb many activity. This Narrowing of channel happens in the Leuwipanjang Terminal, in Kopo Highway Underpass, and garbage dominant in channel near market.

Sub-Catchment Citepus has Main Drain which are Citepus River and its tributaries which consist from Ciroyom River and Cikakak, schematically can be provided in following Figures.

If observed, the density in the upstream of Figure 2, consist several tributaries that flows discharge to Citepus River, which are Cilimus River, Cikakak River, Cipedes River, Sukamulya River, Sukahaji River, Cibogo River, and Ciroyom River. The width of catchment area Sub-Catchment Citepus is $\pm 2330,05$ ha and covers the area that starts from Ledeng in the north until the borders of Kabupaten Bandung in the south.

The River Network that happens naturally already available in Sub-Catchment Citepus is very dense, the convergent character from the tributaries is already going to one river, which is Citepus River. So, the accumulation of the stream from runoff in the downstream part has to be checked along with the condition of Citepus River hydraulics, so the case of backwater that cause runoff will not happen. 


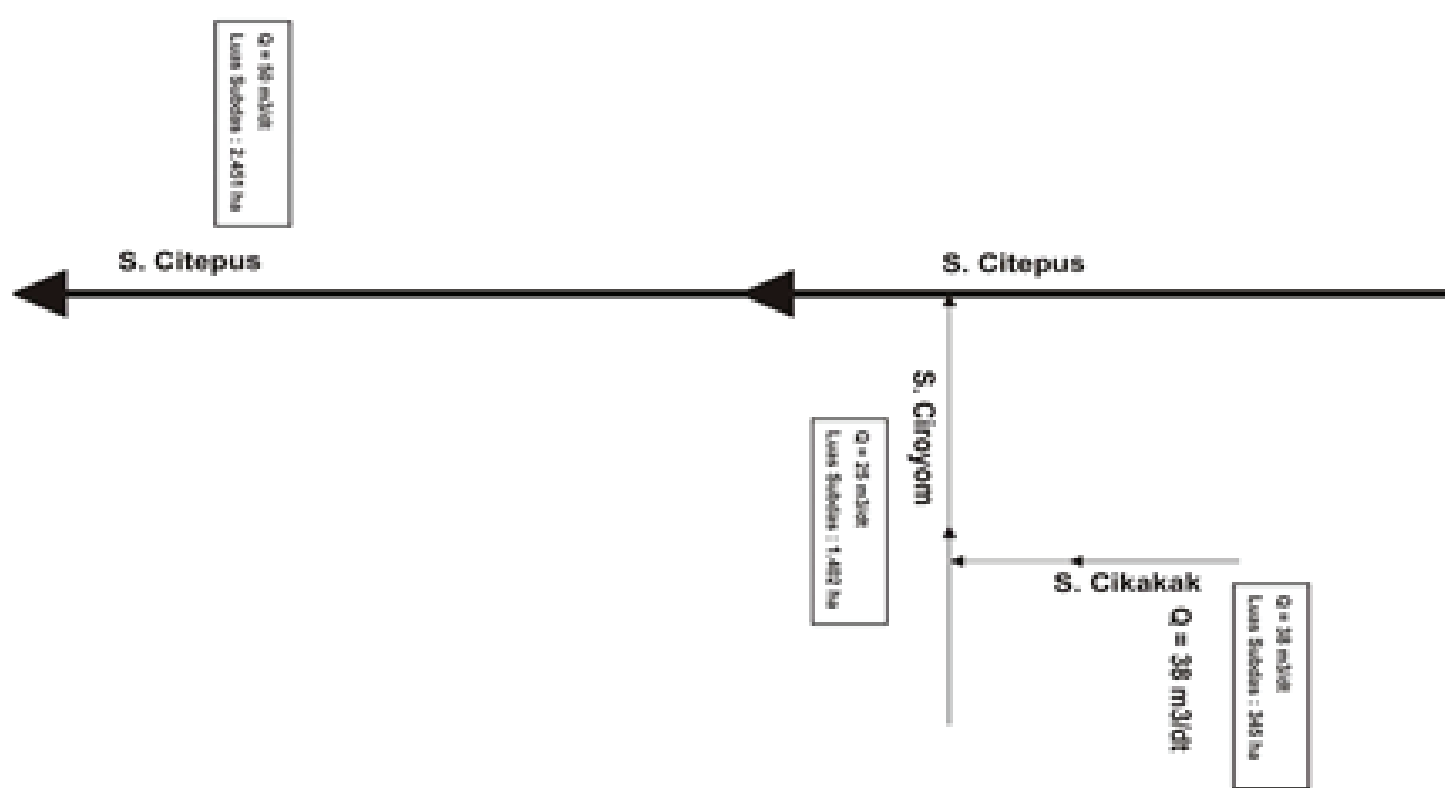

Figure 5: Citepus River Schema.

\section{Conclusion}

1. The Channel capacity that is unable to contain stream of discharge in 2 years has to be re-design.

2. When redesigning channel, the drainage network has to measure to outlet can flow to the main drain without obstruction.

3. The channel capacity that can still contain stream has to be cleared from obstruction that can decrease the capacity of containing wet channel.

4. The carrying of garbage during rainfall is still dominant, as the material that can clog the channel, so even technically the capacity can still contain the stream, it will still overflow.

5. The level of awareness of the people in the city is still low and it is proven by the stacks of garbage in the channel and river.

6. The economy growth in the city as the trigger for the urban people to stay in the land that should not be, many shopkeeper can potentially close the sidewalk and channel as the place to sell, that cause the throwing of garbage to the channel and river.

\section{References}

[1] Bambang Triatmodjo. (2009). Hidrologi Terapan. Beta Offset. Yogyakarta. 
[2] Departemen Pekerjaan Umum.(1987). Pedoman Perencanaan Hidrologi dan Hidrolika Untuk Bangunan di Sungai. Yayasan Badan Penerbit Pekerjaan Umum. Jakarta.

[3] Dinas Bina Marga dan Pengairan Kota Bandung.(2010). Perencanaan Induk Sistem Drainase Kota (Tahap II). Bandung.

[4] Hindarko, S. (2000).Drainase Perkotaan. Penerbit Esha. Jakarta.

[5] Hindarko, S. (2007).Drainase Kawasan Daerah. Penerbit Esha. Jakarta.

[6] Ned H.C. Hwang.(1981). Fundamentals of Hydraulic Engineering Systems. PrenticeHall. Inc. USA.

[7] Suripin.(2004)Sistem Drainase Perkotaan yang Berkelanjutan. Penerbit Andi. Yogyakarta.

[8] Suyono Sosrodarsono, Masateru Tominaga.(1994).Perbaikan dan Pengaturan Sungai. PT. Pradnya Paramitra. Jakarta.

[9] Wesli.(2008).Drainase Perkotaan. Edisi Pertama. Graha Ilmu. Yogyakarta. 